Article

\title{
Ozone catalytic oxidation of benzene over AgMn/HZSM-5 catalysts at room temperature: Effects of Mn loading and water content
}

\author{
Yang Liu, Xiaosong Li, Jinglin Liu, Chuan Shi, Aimin Zhu* \\ Laboratory of Plasma Physical Chemistry, Dalian University of Technology, Dalian 116024, Liaoning, China
}

\section{A R T I C L E I N F O}

Article history:

Received 22 January 2014

Accepted 3 March 2014

Published 20 September 2014

Keywords:

Catalytic oxidation of benzene

Ozone

AgMn/HZSM-5 catalyst

Mn loading

Water vapor

\begin{abstract}
A B S T R A C T
The effects of Mn loading and water content on AgMn/HZSM-5 (AgMn/HZ) catalysts were investigated in the ozone catalytic oxidation (OZCO) of benzene in a continuous air flow at room temperature. The catalytic activity is closely related to the Mn loading, and the AgMn/HZ catalyst with 2.4 wt\% Mn (AgMn/HZ(2.4)) had the highest activity and stability in benzene oxidation as a result of its large surface area and high $\mathrm{MnO}_{x}$ dispersion. Temperature-programmed desorption of the used catalysts demonstrated that $2.4 \mathrm{wt} \%$ was also the optimal Mn loading for suppressing the accumulation of benzene and $\mathrm{HCOOH}$ over the catalyst surface after benzene oxidation. For AgMn/HZ catalysts with Mn loadings $\leq 2.4 \mathrm{wt} \%, \mathrm{O}_{3}$ decomposition to active oxygen species ( $\mathrm{O}^{*}$ ) plays the most important role in benzene oxidation; however, benzene activation is the crucial step for benzene oxidation by $\mathrm{O}_{3}$ over $\mathrm{AgMn} / \mathrm{HZ}$ catalysts with Mn loadings > $2.4 \mathrm{wt} \%$. The AgMn/HZ(2.4) catalyst was then used to perform OZCO of benzene in a humid stream. Compared with dry gas, water vapor greatly enhanced the activity and stability of the $\mathrm{AgMn} / \mathrm{HZ}(2.4)$ catalyst, and $0.1-0.2 \mathrm{vol} \%$ was the optimal water content for benzene oxidation.
\end{abstract}

(C) 2014, Dalian Institute of Chemical Physics, Chinese Academy of Sciences. Published by Elsevier B.V. All rights reserved.

\section{Introduction}

Benzene, a typical volatile organic compound (VOC), has mutagenic, teratogenic, and carcinogenic activities and is known to contribute to poor air quality and to impose serious threats to human health. It is therefore important to strip flues of residual benzene to ensure safety [1].

$\mathrm{O}_{3}$, which is a strong oxidant, has been widely used for the purification of gaseous and aqueous wastes [2-5]. $\mathrm{O}_{3}$ has attracted extensive attention and is now being widely investigated in the catalytic removal of toxic substances from polluted gases because its performance in such reactions is superior to those of $\mathrm{O}_{2}$. It should be noted that there are two factors that regulate catalytic processes: low reaction temperatures and high activities [6]. A Bulgarian group showed that using $\mathrm{O}_{3}$ as the oxidant guaranteed high catalytic activity and enabled the reaction to proceed at low temperatures [7-10]. Specifically, the data obtained using manganese oxide as the catalyst demonstrated that the activation energy in catalytic benzene oxidation using $\mathrm{O}_{3}$ was three times lower than that using $\mathrm{O}_{2}$ [7].

Several excellent reports on ozone catalytic oxidation (OZCO) of gaseous benzene have been published. Einaga and coworkers [11] mainly investigated the catalytic activities of manganese oxides supported on $\mathrm{Al}_{2} \mathrm{O}_{3}$ in benzene oxidation with $\mathrm{O}_{3}$ and clarified the relationship between the behavior of benzene, $\mathrm{CO}_{x}$, and $\mathrm{O}_{3}$. They also studied the effects of the catalyst supports $\left(\mathrm{SiO}_{2}, \mathrm{Al}_{2} \mathrm{O}_{3}, \mathrm{TiO}_{2}\right.$, and $\left.\mathrm{ZrO}_{2}\right)$ on benzene oxidation by $\mathrm{O}_{3}$ over supported $\mathrm{Mn}$ catalysts in detail and found a good positive linear correlation between the reaction rate and the catalyst surface area [12]. The activities in benzene oxidation of

* Corresponding author. Tel/Fax: +86-411-84706094; E-mail: amzhu@dlut.edu.cn

This work was supported by the National Natural Science Foundation of China (U1201231, 11175036).

DOI: 10.1016/S1872-2067(14)60070-X | http://www.sciencedirect.com/science/journal/18722067 | Chin. J. Catal., Vol. 35, No. 9, September 2014 
various catalyst components $(\mathrm{Mn}, \mathrm{Ag}, \mathrm{Co}, \mathrm{Ni}, \mathrm{Fe}$, and $\mathrm{Cu}$ ) on $\mathrm{Al}_{2} \mathrm{O}_{3}$ have been studied, and it was found that an Fe sample had the highest activity for $\mathrm{O}_{3}$ decomposition in the absence of organic substrates, and an Mn sample was most suitable for benzene oxidation and $\mathrm{O}_{3}$ decomposition in the presence of organic compounds [13]. The effects of catalyst loading were also studied, and it was found that lower Mn loadings were more favorable in OZCO of benzene because of the higher dispersion of Mn [14]. Mehandjiev and coworkers [15,16] prepared several types of highly active samples such as ilmenite-type $\mathrm{NiMnO}_{3}, \mathrm{Al}_{2} \mathrm{O}_{3}$-supported $\mathrm{Cu}$-Cr and $\mathrm{Co}-\mathrm{Cr}$ [8], and furnace-slag-supported $\mathrm{Cu}, \mathrm{Co}, \mathrm{Mn}$, and $\mathrm{Ni}$ [9] and investigated their activities in $\mathrm{O}_{3}$ decomposition and benzene oxidation. It has also been established that the oxygen species formed during $\mathrm{O}_{3}$ decomposition at the active sites contribute greatly to accelerating the reaction rate and decreasing the reaction temperature [8,17].

As mentioned above, OZCO generally proceeds at lower temperatures compared with conventional catalytic oxidation processes, but the catalysts usually suffer from gradual deactivation because of the accumulation of less-reactive byproducts on the catalyst surface $[11,13,18-21]$; catalyst stability under mild conditions is therefore a problem. Catalyst heating is one of the methods frequently used to overcome this problem [19], but this consumes large amounts of energy. It has been demonstrated that the addition of water vapor can improve the catalytic activity and suppress catalyst deactivation by inhibiting the accumulation of organic intermediates on catalysts $[22,23]$. In addition, we reported that about $100 \%$ of formaldehyde could be oxidized to $\mathrm{CO}_{2}$ by $\mathrm{O}_{3}$ in humid air streams [24].

Manganese oxide has frequently been used as one of the catalytically active constituents for OZCO of benzene and $\mathrm{O}_{3}$ decomposition [7,11,23,25-27] because of its excellent $\mathrm{O}_{3}$-decomposing ability and high oxidation rate. It was also clearly shown that an $\mathrm{Al}_{2} \mathrm{O}_{3}$-supported $\mathrm{Ag}$ catalyst was another potential candidate for this process because it promoted oxidation of intermediates on the catalyst [18].

In our previous study, we investigated the catalytic oxidation of adsorbed benzene by $\mathrm{O}_{3}$ over $\mathrm{AgMn} / \mathrm{HZ}$ ( $\mathrm{HZ}=\mathrm{HZSM}-5$ ) catalysts for the first time. We found that Ag played an important role in promoting the complete oxidation of benzene and that $\mathrm{MnO}_{x}$ addition not only facilitated $\mathrm{O}_{3}$ decomposition but also accelerated the oxidation of benzene adsorbed on Ag sites. However, the effects of Mn loading need to be thoroughly investigated for catalyst optimization, and the optimal water content for suppressing catalyst deactivation is also an important issue.

In this study, we first investigated the effects of Mn loading on the behavior of AgMn/HZ catalysts in OZCO of benzene in a dry continuous air flow and determined the optimal Mn loading. OZCO of gaseous benzene over an AgMn/HZ catalyst with the optimal Mn loading in humid air streams with different water contents was then carried out, and the optimal water content was determined.

\section{Experimental}

\subsection{Catalyst preparation}

$\mathrm{Ag} / \mathrm{HZ}$ and $\mathrm{AgMn} / \mathrm{HZ}$ catalysts were prepared using an incipient wetness impregnation method. $\mathrm{AgNO}_{3}$ and $\mathrm{Mn}\left(\mathrm{CH}_{3} \mathrm{COO}\right)_{2} \cdot 4 \mathrm{H}_{2} \mathrm{O}$ were used as $\mathrm{Ag}$ and Mn precursors, respectively. The impregnated samples were stirred for $30 \mathrm{~min}$, aged overnight at ambient temperature in darkness, dried at $110{ }^{\circ} \mathrm{C}$ for $6 \mathrm{~h}$ and calcined at $450{ }^{\circ} \mathrm{C}$ for $3 \mathrm{~h}$. The obtained powders were grounded, tableted, crushed and sieved to 20-40 mesh. The nominal Ag loading of all the samples was fixed at 1 wt $\%$ based on our previous study, which showed that the 0.8 wt $\% \mathrm{Ag} / \mathrm{HZ}$ catalyst gave an excellent performance in plasma catalytic oxidation of stored benzene [28,29]. For the AgMn/HZ catalysts, the Mn loading was varied and seven samples were prepared.

\subsection{Catalyst characterization}

The elemental compositions of $\mathrm{Ag}$ and $\mathrm{Mn}$ in the catalysts were analyzed using inductively coupled plasma-atomic emission spectroscopy (Optima 2000DV, Perkin Elmer, USA). The Ag loading of the $\mathrm{Ag} / \mathrm{HZ}$ catalyst was $0.7 \mathrm{wt} \%$, and the $\mathrm{Ag}$ and Mn loadings of the seven AgMn/HZ catalysts were 0.8 wt $\%$ and $0.8 w t \%, 0.8 w t \%$ and $1.7 w t \%, 0.7 w t \%$ and $2.4 w t \%, 0.7 w t \%$ and $3.2 \mathrm{wt} \%, 0.7 \mathrm{wt} \%$ and $4.3 \mathrm{wt} \%, 0.7 \mathrm{wt} \%$ and $5.1 \mathrm{wt} \%$, and $0.7 \mathrm{wt} \%$ and $6.4 \mathrm{wt} \%$. The $\mathrm{AgMn} / \mathrm{HZ}$ catalysts were named based on the Mn loadings, i.e., $\operatorname{AgMn} / \operatorname{HZ}(a)$ refers to a catalyst containing $a \mathrm{wt} \% \mathrm{Mn}$. The specific surface area of the catalysts was measured using the $\mathrm{N}_{2}$ adsorption BET method at $-196{ }^{\circ} \mathrm{C}$ (Autosorb-1, Quantachrome, USA). Diffuse reflectance spectra (DRS) of the catalysts were recorded in the range $200-800 \mathrm{~nm}$ at room temperature using a UV-vis spectrophotometer (Cary 5000, Agilent, USA). The spectra were obtained by subtraction of the HZSM-5 support spectrum from those of the $\mathrm{Ag} / \mathrm{HZ}$ or AgMn/HZ catalysts. The redox behavior was evaluated by temperature-programmed reduction (TPR) using a chemisorption analyzer (Autochem II 2920, Micromeritics, USA). The sample (100 mg) was pretreated in a 50 SCCM (standard cubic centimeters per minute) dry simulated air stream at $450{ }^{\circ} \mathrm{C}$ for $1 \mathrm{~h}$ and then cooled to room temperature in a $\mathrm{N}_{2}$ stream. The TPR experiments were performed using $5 \% \mathrm{H}_{2}$ in $\mathrm{Ar}$ at a flow rate of $50 \mathrm{SCCM}$. The temperature was increased to $450{ }^{\circ} \mathrm{C}$ at a heating rate of $10^{\circ} \mathrm{C} / \mathrm{min}$.

\subsection{OZCO reactions}

The catalytic reactions were carried out using a fixed-bed flow reactor. Figure 1 shows a schematic diagram of the experimental setup. A quartz U-tube reactor (i.d. $4 \mathrm{~mm}$ ) containing about $53 \mathrm{mg}$ of catalyst (20-40 mesh particles) was immersed in a water bath at $25^{\circ} \mathrm{C} . \mathrm{O}_{3}$ was generated from $\mathrm{O}_{2}$ using a laboratory-made $\mathrm{O}_{3}$ generator and monitored online using Fourier-transform infrared (FT-IR) spectroscopy (Nicolet-Antaris IGS Analyzer, Thermo, USA). Water vapor was carried by $\mathrm{N}_{2}$ and $\mathrm{O}_{2}$ flowing through a bubbler placed in a water bath at $25{ }^{\circ} \mathrm{C}$, and the water concentration was measured online using a dew point hygrometer (635-2, Testo, Germany). 


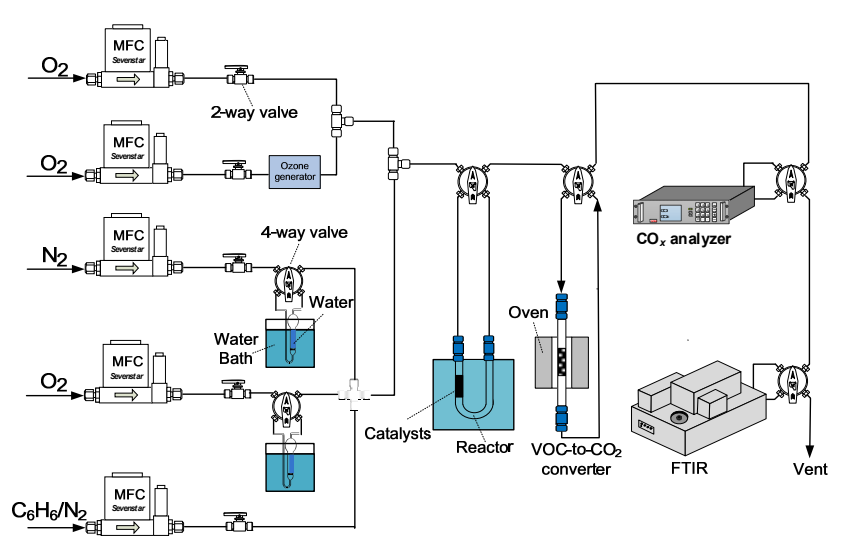

Fig. 1. Schematic diagram of experimental setup.

The desired water content was adjusted by varying the carrier gas flow rates. Prior to the reactions, all catalysts were pretreated in a dry simulated air stream at $450{ }^{\circ} \mathrm{C}$ for $1 \mathrm{~h}$ and then cooled to room temperature in a $\mathrm{N}_{2}$ stream. The reaction gas mixture, dry or humid simulated air containing benzene and $\mathrm{O}_{3}$, was flowed through the catalyst bed at a total flow rate of 250 SCCM, corresponding to a gas hourly space velocity of 170609 $\mathrm{h}^{-1}$. The initial benzene concentration was measured based on its conversion to $\mathrm{CO}_{2}$ using a laboratory-made VOC-to- $\mathrm{CO}_{2}$ converter $\left(10 \% \mathrm{Cu} / 10 \% \mathrm{Mn} / \gamma-\mathrm{Al}_{2} \mathrm{O}_{3}\right.$ catalyst $)$ at $400{ }^{\circ} \mathrm{C}$, and the concentration of $\mathrm{CO}_{2}$ was monitored online using a $\mathrm{CO}_{x}$ analyzer (S710, Sick-Maihak, Germany) [30]. The following conditions were used for the oxidation: $862-901 \mathrm{mg} / \mathrm{m}^{3} \mathrm{O}_{3}$ and 143-153 mg/m³ benzene. Gas samples in the outlet were analyzed using the $\mathrm{CO}_{x}$ analyzer and FT-IR spectrometer. The catalyst deactivation rate (DR) was defined as follows:

$$
\begin{aligned}
& \text { DR- }{ }_{6} \mathrm{H}_{6}\left(\mu \mathrm{mol} \mathrm{g}-1 \mathrm{~min}^{-2}\right)=\left[\mathrm{C}^{\mathrm{in}} \mathrm{C}_{6 \mathrm{H}} 6 \times\left(X^{0}{ }_{\mathrm{C} 6 \mathrm{H} 6}-X^{\mathrm{TOS}}=60 \mathrm{~min}_{\mathrm{C} 6 \mathrm{H} 6}\right)\right] \\
& \times\left[F_{1} /\left(V_{\mathrm{m}} \times m_{\text {cat }} \times 60\right)\right] \\
& \text { DR- }{ }_{3}\left(\mu \mathrm{mol} \mathrm{g}-1 \mathrm{~min}^{-2}\right)=\left[\mathrm{Cin}^{\mathrm{in}} \times\left(X_{03}{ }_{03}-X^{\mathrm{TOS}}=60 \mathrm{~min}_{03}\right)\right] \times \\
& {\left[F_{1} /\left(V_{\mathrm{m}} \times m_{\text {cat }} \times 60\right)\right]}
\end{aligned}
$$

where $C^{\mathrm{in}} 6 \mathrm{H}_{6}$ and $C^{\mathrm{in}} 03$ are the benzene and $\mathrm{O}_{3}$ concentrations

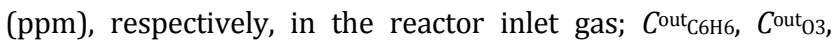

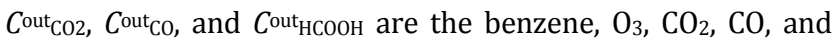
$\mathrm{HCOOH}$ concentrations (ppm), respectively, in the reactor outlet gas; $X^{0}{ }_{6} 6 \mathrm{H} 6$ and $X^{0} 03$ are the benzene and $\mathrm{O}_{3}$ conversions (\%),

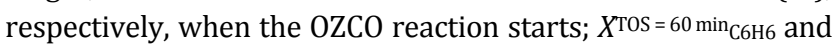
$X^{\mathrm{TOS}}=60 \mathrm{~min}_{03}$ are the benzene and $\mathrm{O}_{3}$ conversions (\%), respectively, at time-on-stream (TOS) $=60 \mathrm{~min} ; V_{\mathrm{m}}$ is the molar volume $(22400 \mathrm{ml} / \mathrm{mol}), m_{\text {cat }}$ is the mass of catalyst $(\mathrm{g})$, and $F_{1}$ is the total flow rate (SCCM) during OZCO.

$\mathrm{CO}_{x}$ and $\mathrm{HCOOH}$ were the only carbon-containing products detected by FT-IR spectroscopy in all cases, so the carbon balance for $\mathrm{OZCO}\left(\mathrm{BOZCO}_{\mathrm{C}}, \%\right)$ is defined as follows:

$$
B^{\mathrm{OZCO}_{\mathrm{C}}}=\mathrm{S}_{\mathrm{CO} 2}+S_{\mathrm{CO}}+S_{\mathrm{HCOOH}}
$$

where $S_{\mathrm{CO} 2}, S_{\mathrm{CO}}$, and $S_{\mathrm{HCOOH}}$ are the selectivities (\%) of $\mathrm{CO}_{2}, \mathrm{CO}$, and $\mathrm{HCOOH}$, respectively.

Neither benzene oxidation nor $\mathrm{O}_{3}$ decomposition was observed without a catalyst; therefore homogeneous gaseous reactions of benzene with $\mathrm{O}_{3}$ can be neglected.

\subsection{Temperature-programmed desorption (TPD) and temperature-programmed oxidation (TPO) of used catalysts}

TPD and TPO analyses were performed on the catalysts that had been used in the OZCO process. The reactor system was the same as that described above. After OZCO, the reaction gas was switched to $\mathrm{N}_{2}$ (for TPD) or dry simulated air (for TPO), with a flow rate of 90 SCCM. After purging for over $40 \mathrm{~min}$ at room temperature, the catalyst was heated at a rate of $10{ }^{\circ} \mathrm{C} / \mathrm{min}$ to $450{ }^{\circ} \mathrm{C}$ and then the temperature was kept constant for $30 \mathrm{~min}$. The products in the effluent gas were detected by the $\mathrm{CO}_{x}$ analyzer and FT-IR spectrometer. The percentages of desorbed benzene and $\mathrm{HCOOH}$ detected by TPD were defined as follows: Benzene desorbed (\%) $=\left[\int_{t 1}^{t 2} F_{2} C^{t}{ }_{\mathrm{C} 6 \mathrm{H} 6} \mathrm{~d} t / \int_{0}^{120} F_{1} C^{\mathrm{in}}{ }_{\mathrm{C} 6 \mathrm{H} 6} X^{t}{ }_{\mathrm{C} 6 \mathrm{H} 6} \mathrm{~d} t\right] \times$ $100 \%$

$$
\begin{gathered}
\text { HCOOH desorbed }(\%)=\left[\int_{t 1}^{t 2} F_{2} C t_{\mathrm{HCOOH}} \mathrm{d} t /\left(6 \times \int_{0}^{120}\right.\right. \\
\left.\left.F_{1} C^{\mathrm{in}} \mathrm{C}_{6 \mathrm{H} 6} X^{t_{\mathrm{C}} 6 \mathrm{H} 6} \mathrm{~d} t\right)\right] \times 100 \%
\end{gathered}
$$

where $C^{t}{ }^{6} 6 \mathrm{H} 6$ and $C^{t}{ }_{\mathrm{HCOOH}}$ are the benzene and $\mathrm{HCOOH}$ concentrations (ppm) evolved at $t$ min in the TPD process, respectively; $X^{t_{\mathrm{C}} \mathrm{H} 6}$ is the benzene conversion (\%) at TOS $=t$ min during OZCO; $F_{2}, t_{1}$, and $t_{2}$ are the total flow rate (SCCM), and any moment $\left(t_{1}<t_{2}\right)$ (min), respectively, during TPD.

\section{5. $\mathrm{O}_{3}$ decomposition measurements without benzene}

$\mathrm{O}_{3}$ decomposition in the absence of benzene was also carried out over the catalysts in the reactor system described above. $\mathrm{O}_{3} / \mathrm{O}_{2}$ at $100 \mathrm{SCCM}$ was flowed through the reactor, containing about $27 \mathrm{mg}$ of catalyst, and the inlet $\mathrm{O}_{3}$ concentration was in the range $862-921 \mathrm{mg} / \mathrm{m}^{3}$. The outlet $\mathrm{O}_{3}$ was quantified using FT-IR spectroscopy.

\section{Results and discussion}

\subsection{Physicochemical properties of catalysts}

The BET surface areas were 341, 340, 326, 336, 299, 268, 278, and $274 \mathrm{~m}^{2} / \mathrm{g}$, respectively, for $\mathrm{Ag} / \mathrm{HZ}, \mathrm{AgMn} / \mathrm{HZ}(0.8)$, AgMn/HZ(1.7), AgMn/HZ(2.4), AgMn/HZ(3.2), AgMn/HZ(4.3), AgMn/HZ(5.1), and AgMn/HZ(6.4). The Ag loading did not decrease the surface area of $\mathrm{Ag} / \mathrm{HZ}$ compared with the bare $\mathrm{HZ}$ support $\left(341 \mathrm{~m}^{2} / \mathrm{g}\right.$ ) $[28,29]$ because the loading was very low. For the AgMn/HZ catalysts, almost no changes were observed in the surface area when the Mn loading was $\leq 2.4 \mathrm{wt} \%$. However, further increasing the Mn loading to $3.2 \mathrm{wt} \%$ significantly decreased the AgMn/HZ surface area to $299 \mathrm{~m}^{2} / \mathrm{g}$; this could be ascribed to the formation of large $\mathrm{MnO}_{x}$ particles over the catalyst surface, which would block the pores of the HZ support [31]. When the Mn loading was $\geq 4.3 \mathrm{wt} \%$, the surface areas remained nearly unchanged at around $270 \mathrm{~m}^{2} / \mathrm{g}$. Based on the BET data, it can be deduced that the $2.4 \mathrm{wt} \% \mathrm{Mn}$ loading was a turning point, above which large $\mathrm{MnO}_{x}$ particles were formed, resulting in observable decreases in the surface areas of the AgMn/HZ catalysts.

Figure 2 shows the UV-vis DRS of the $\mathrm{Ag} / \mathrm{HZ}$ and $\mathrm{AgMn} / \mathrm{HZ}$ catalysts. UV-vis DRS can provide information on the metal oxidation state and its chemical environment. The $\mathrm{Ag} / \mathrm{HZ}$ sample exhibited two bands centered at 264 and $413 \mathrm{~nm}$, assigned to $\mathrm{Ag}$ clusters and $\mathrm{Ag}^{0}$, respectively [32,33]. All the Mn-containing samples exhibited two bands at 279 and $499 \mathrm{~nm}$, char- 


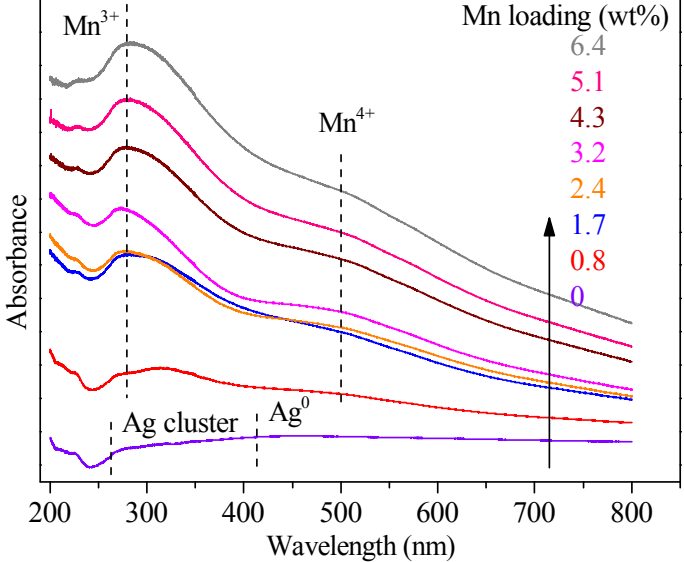

Fig. 2. UV-vis DRS of $\mathrm{Ag} / \mathrm{HZ}$ and $\mathrm{AgMn} / \mathrm{HZ}$ catalysts.

acteristic of $\mathrm{Mn}^{3+}$ and $\mathrm{Mn}^{4+}$, respectively [31]. The UV-vis DRS data were consistent with the previous results that Ag was present in the metallic state in the $\mathrm{Ag} / \mathrm{HZ}$ and $\mathrm{AgMn} / \mathrm{HZ}$ catalysts, and $\mathrm{Mn}$ in the $\mathrm{AgMn} / \mathrm{HZ}$ catalysts was present as $\mathrm{Mn}^{3+}$ and $\mathrm{Mn}^{4+}$.

The $\mathrm{H}_{2}$-TPR results are shown in Fig. 3. No reduction peak was observed for $\mathrm{Ag} / \mathrm{HZ}$ (data not shown), and this result is in good accordance with the UV-vis DRS data, which showed that Ag was present in the metallic state on the zeolite. For all the $\mathrm{AgMn} / \mathrm{HZ}$ catalysts, two reduction peaks were observed, ascribable to the sequential reduction of $\mathrm{MnO}_{2}$ to $\mathrm{Mn}_{2} \mathrm{O}_{3}$ and $\mathrm{Mn}_{2} \mathrm{O}_{3}$ to $\mathrm{MnO}$, respectively. Because $\mathrm{Ag}$ was present in the metallic state, Ag could not be reduced. As shown in Fig. 3, the low-temperature reduction peaks were centered at 158, 157, and $156{ }^{\circ} \mathrm{C}$ for the AgMn/HZ(0.8), AgMn/HZ(1.7), and AgMn/ $\mathrm{HZ}(2.4)$ catalysts, respectively, and at $195,190,198$, and $194{ }^{\circ} \mathrm{C}$ for the $\mathrm{AgMn} / \mathrm{HZ}(3.2), \operatorname{AgMn} / \mathrm{HZ}(4.3), \operatorname{AgMn} / \mathrm{HZ}(5.1)$, and AgMn/HZ(6.4) catalysts, respectively. The high-temperature reduction peaks were located at 217,211 , and $226{ }^{\circ} \mathrm{C}$ for the $\mathrm{AgMn} / \mathrm{HZ}(0.8), \mathrm{AgMn} / \mathrm{HZ}(1.7)$, and AgMn/HZ(2.4) catalysts, respectively, and at 271,268, 274, and $285{ }^{\circ} \mathrm{C}$ for the $\mathrm{AgMn} / \mathrm{HZ}(3.2), \mathrm{AgMn} / \mathrm{HZ}(4.3), \mathrm{AgMn} / \mathrm{HZ}(5.1)$, and AgMn/ HZ(6.4) catalysts, respectively. The reduction temperatures shifted to higher temperatures when the Mn loadings were

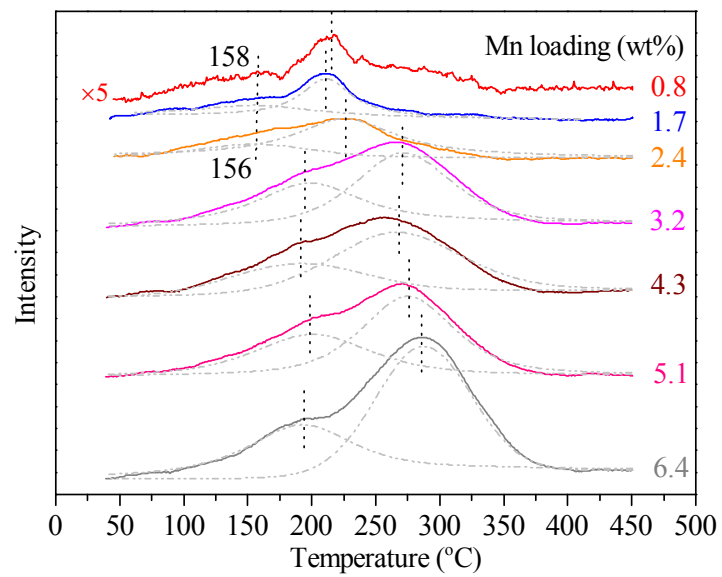

Fig. 3. $\mathrm{H}_{2}-\mathrm{TPR}$ profiles of the AgMn/HZ catalysts. Conditions: $100 \mathrm{mg}$ of catalyst, $50 \mathrm{SCCM}$ of $5 \% \mathrm{H}_{2} / \mathrm{Ar}, 10^{\circ} \mathrm{C} / \mathrm{min}$. higher than $2.4 \mathrm{wt} \%$. This indicates that the $\mathrm{AgMn} / \mathrm{HZ}$ catalysts with Mn loadings $\leq 2.4 \mathrm{wt} \%$ were more easily reduced than the $\mathrm{AgMn} / \mathrm{HZ}$ catalysts with Mn loadings > $2.4 \mathrm{wt} \%$. Moreover, it has been reported that the reduction temperature for a given metal oxide depends on the dispersion of the metal oxide, and highly dispersed metal oxides can be reduced at lower temperatures than their aggregated counterparts [27,34,35]. It is therefore rational to deduce that large $\mathrm{MnO}_{x}$ particles were formed on the $\mathrm{AgMn} / \mathrm{HZ}$ catalysts when the Mn loadings were higher than $2.4 \mathrm{wt} \%$, which is in good agreement with the BET data.

Based on the sequential reduction steps $\mathrm{MnO}_{2}+1 / 2 \mathrm{H}_{2} \rightarrow$ $1 / 2 \mathrm{Mn}_{2} \mathrm{O}_{3}$ and $1 / 2 \mathrm{Mn}_{2} \mathrm{O}_{3}+1 / 2 \mathrm{H}_{2} \rightarrow \mathrm{MnO}$, and the assumption of complete reduction, $\mathrm{Mn}^{3+} / \mathrm{Mn}^{4+}$ atomic ratios of $9.5,0.5,3.3$, $0.3,1.0,0.5$, and 0.5 were calculated for the $\operatorname{AgMn} / \mathrm{HZ}(0.8)$, AgMn/HZ(1.7), AgMn/HZ(2.4), AgMn/HZ(3.2), AgMn/HZ(4.3), $\mathrm{AgMn} / \mathrm{HZ}(5.1)$, and AgMn/HZ(6.4) catalysts, respectively.

\subsection{OZCO of benzene in dry continuous flow}

The catalytic performance of the $\mathrm{Ag} / \mathrm{HZ}$ and $\mathrm{AgMn} / \mathrm{HZ}$ catalysts was evaluated in the OZCO of gaseous benzene; the results are presented in Fig. 4. Figure 4(a) and (b) show the variations in benzene conversion and $\mathrm{O}_{3}$ decomposition with Mn loading at different TOS during benzene oxidation in dry air on the $\mathrm{Ag} / \mathrm{HZ}$ and $\mathrm{AgMn} / \mathrm{HZ}$ catalysts. Both benzene conversion and $\mathrm{O}_{3}$ decomposition declined with increasing TOS, indicating catalyst deactivation during benzene oxidation. It was found that the addition of $\mathrm{MnO}_{x}$ to $\mathrm{Ag} / \mathrm{HZ}$ significantly influenced the catalytic activity, and the catalytic performance of $\mathrm{AgMn} / \mathrm{HZ}$ strongly depended on the Mn loading. Specifically, the benzene conversion and $\mathrm{O}_{3}$ decomposition increased with increasing $\mathrm{Mn}$ loading when the loading was $\leq 2.4 \mathrm{wt} \%$ because of the increasing $\mathrm{O}_{3}$ decomposition activities of the catalysts as a result of the high $\mathrm{O}_{3}$ decomposition activity of $\mathrm{MnO}_{x}$. The $\mathrm{AgMn} / \mathrm{HZ}(2.4)$ catalyst showed the best benzene conversion and $\mathrm{O}_{3}$ decomposition. However, when the Mn loading was higher than $2.4 \mathrm{wt} \%$, the benzene conversion and $\mathrm{O}_{3}$ decomposition decreased with increasing Mn loading; this is ascribed to a decrease in the surface area and poor $\mathrm{MnO}_{x}$ dispersion, as shown by the BET and $\mathrm{H}_{2}$-TPR results. Figure 4(c) shows the $\mathrm{CO}_{x}$ selectivity versus $\mathrm{Mn}$ loading during benzene oxidation. It can be seen from Fig. 4(c) that the $\mathrm{CO}_{2}$ selectivities of the $\mathrm{AgMn} / \mathrm{HZ}$ catalysts were higher than that of $\mathrm{Ag} / \mathrm{HZ}$. This is because $\mathrm{MnO}_{x}$ has a high $\mathrm{O}_{3}$ decomposition activity, which might promote complete oxidation of benzene. Moreover, the $\mathrm{CO}_{2}$ selectivity did not change much with $\mathrm{Mn}$ loading when the Mn loading was higher than $0.8 \mathrm{wt} \%$ during the first $60 \mathrm{~min}$, but after $60 \mathrm{~min}$ the $\mathrm{CO}_{2}$ selectivities of the $\mathrm{AgMn} / \mathrm{HZ}$ catalysts with Mn loadings > 3.2 wt $\%$ became higher than those of the catalysts with Mn loadings $\leq 3.2 \mathrm{wt} \%$; this is a result of the fast drop in benzene conversion for the $\mathrm{AgMn} / \mathrm{HZ}$ catalysts with $\mathrm{Mn}$ loadings > 3.2 wt\%, as shown in Fig. 4(a). It should also be noted that for the $\mathrm{Ag} / \mathrm{HZ}$ and $\mathrm{AgMn} / \mathrm{HZ}$ catalysts, the $\mathrm{CO}_{2}$ selectivity gradually increased with increasing TOS. This is because the $\mathrm{CO}_{2}$ concentration did not decrease as much (data not shown) as the benzene conversion did with increasing TOS 

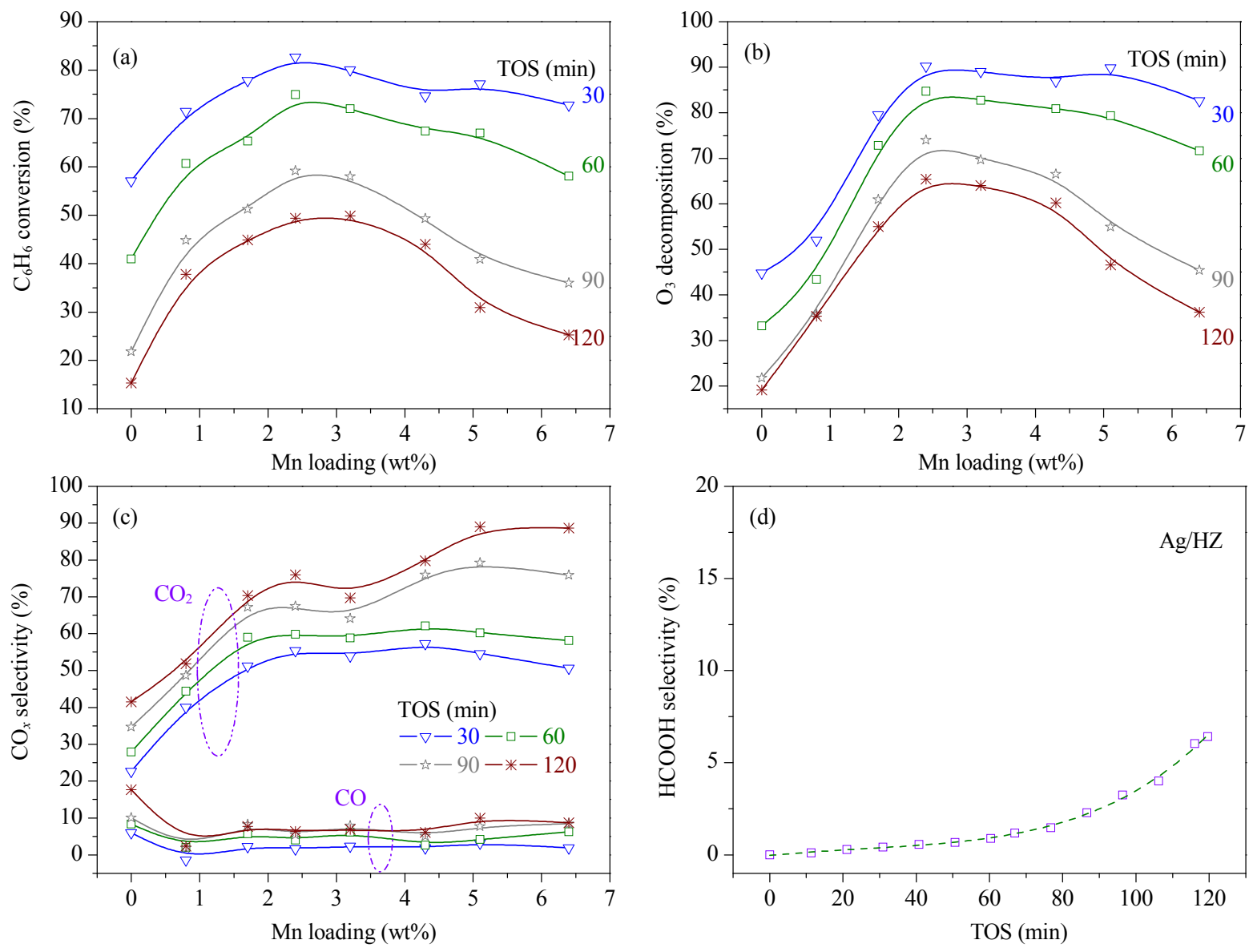

Fig. 4. Dependences of benzene conversion (a), $\mathrm{O}_{3}$ decomposition (b), and $\mathrm{CO}_{x}$ selectivity (c) on $\mathrm{Mn}$ loading at different TOS during OZCO of benzene in dry continuous air flow over $\mathrm{Ag} / \mathrm{HZ}$ and $\mathrm{AgMn} / \mathrm{HZ}$ catalysts; (d) $\mathrm{HCOOH}$ selectivity versus TOS during OZCO of benzene in dry continuous air flow over $\mathrm{Ag} / \mathrm{HZ}$ catalyst. Conditions: $53 \mathrm{mg}$ of catalyst, $143-153 \mathrm{mg} / \mathrm{m}^{3}$ benzene in dry simulated air at $250 \mathrm{SCCM}, 862-901 \mathrm{mg} / \mathrm{m}^{3} \mathrm{O}_{3}$.

during OZCO. Furthermore, the addition of $\mathrm{MnO}_{x}$ slightly reduced the CO selectivity, but there were no obvious differences among the AgMn/HZ catalysts with different Mn loadings. The $\mathrm{AgMn} / \mathrm{HZ}(2.4)$ catalyst showed the best benzene conversion and $\mathrm{O}_{3}$ decomposition; therefore we also carried out benzene oxidation over $\mathrm{Mn} / \mathrm{HZ}$ with $2.3 \mathrm{wt} \% \mathrm{Mn}(\mathrm{Mn} / \mathrm{HZ}(2.3)$ ) for comparison. The benzene conversion and $\mathrm{O}_{3}$ decomposition at $\mathrm{TOS}=60 \mathrm{~min}$ for $\mathrm{Mn} / \mathrm{HZ}(2.3)$ were about $70 \%$ and $86 \%$ (data not shown), respectively, which were inferior to those for AgMn/HZ(2.4), with 75\% benzene conversion. However, more CO was formed over the Mn/HZ(2.3) catalyst and about $12 \%$ CO selectivity was achieved at TOS $=60 \mathrm{~min}$ (data not shown), which means that the addition of Ag promotes complete oxidation of benzene. The addition of Ag did not greatly affect the $\mathrm{CO}_{2}$ selectivity, so, in this regard, the $\mathrm{Ag}$ component also played an important role in benzene oxidation. A small amount of $\mathrm{HCOOH}$ was detected on the $\mathrm{Ag} / \mathrm{HZ}$ catalyst, and the $\mathrm{HCOOH}$ selectivity was plotted against TOS, as shown in Fig. 4(d). No $\mathrm{HCOOH}$ was found in the gaseous phase when the $\mathrm{AgMn} / \mathrm{HZ}$ catalysts were used. The TPD results (discussed later) showed that $\mathrm{HCOOH}$ was also formed over the $\mathrm{AgMn} / \mathrm{HZ}$ catalysts, but the amount was less than that formed over the $\mathrm{Ag} / \mathrm{HZ}$ catalyst, so $\mathrm{HCOOH}$ only accumulated as a byproduct on the $\mathrm{AgMn} / \mathrm{HZ}$ catalyst surfaces during OZCO. If it is assumed that the OZCO of benzene proceeded by the steps benzene oxidation to $\mathrm{HCOOH}$, which is then oxidized to $\mathrm{CO}_{x}$ and water, $\mathrm{MnO}_{x}$ could promote the oxidation of $\mathrm{HCOOH}$ to $\mathrm{CO}_{x}$ and water.

As mentioned before, the catalysts suffered deactivation during OZCO. The dependence of the catalyst deactivation rate on Mn loading is shown in Fig. 5 to elucidate the effect of Mn loading on catalyst deactivation. The DR- $\mathrm{C}_{6} \mathrm{H}_{6}$ curve was para-

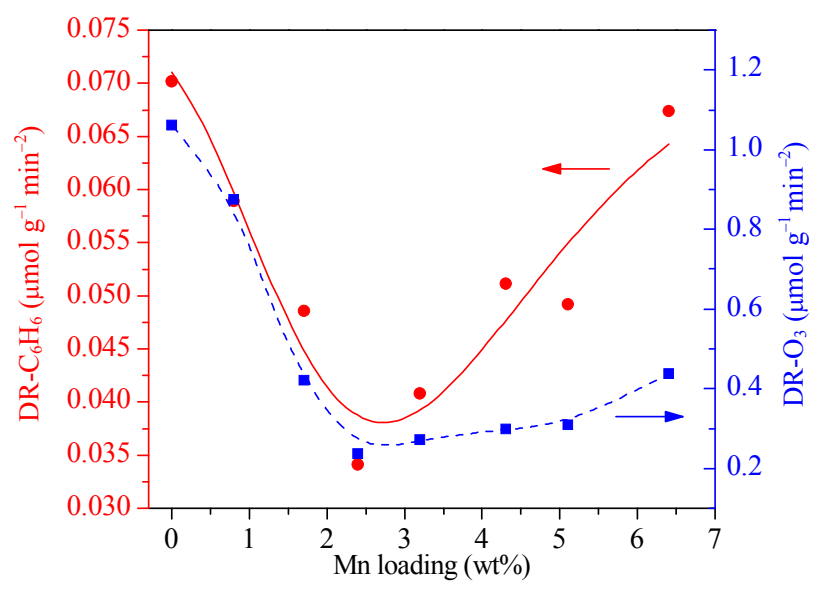

Fig. 5. Effect of Mn loading on catalyst deactivation rate during OZCO of benzene in dry continuous air flow. 
bolic, with a minimum at $2.4 \mathrm{wt} \% \mathrm{Mn}$; this catalyst also showed the lowest $\mathrm{DR}-\mathrm{O}_{3}$. A comparison of these two curves gave interesting results. Specifically, the DR- $\mathrm{C}_{6} \mathrm{H}_{6}$ and DR- $\mathrm{O}_{3}$ curves showed the same trend up to an Mn loading of $2.4 \mathrm{wt} \%$, but after that point $\mathrm{DR}-\mathrm{O}_{3}$ did not change as much with Mn loading as DR- $\mathrm{C}_{6} \mathrm{H}_{6}$ did. A plausible explanation is as follows. When the Mn loading was $\leq 2.4 \mathrm{wt} \%, \mathrm{O}_{3}$ decomposition to active oxygen species $\left(\mathrm{O}^{*}\right)$ was the key step in determining the benzene conversion, and higher benzene conversions were related to better $\mathrm{O}_{3}$ decomposition. It can be seen from Fig. 4(a) and (b) that both benzene conversion and $\mathrm{O}_{3}$ decomposition increased with increasing Mn loading when the Mn loading was $\leq 2.4 \mathrm{wt} \%$. The catalyst stability during benzene conversion therefore depended on the $\mathrm{O}_{3}$ decomposition when the Mn loading was $\leq$ $2.4 \mathrm{wt} \%$. However, large $\mathrm{MnO}_{x}$ particles were probably formed when the Mn loading was higher than $2.4 \mathrm{wt} \%$, which would result in coverage of $\mathrm{Ag}$ sites. As revealed previously, Ag was responsible for benzene activation and $\mathrm{O}_{3}$ was mainly decomposed on $\mathrm{MnO}_{x}$ to active oxygen species, which could then oxidize benzene. The coverage of Ag would hinder benzene activation. So, the higher the Mn loading was, the faster the DR- $\mathrm{C}_{6} \mathrm{H}_{6}$ was. It is therefore reasonable to deduce that when the $\mathrm{Mn}$ loading was $\leq 2.4 \mathrm{wt} \%, \mathrm{O}_{3}$ decomposition to $\mathrm{O}^{*}$ played the most important role in benzene oxidation, whereas benzene activation was the crucial step for benzene oxidation by $\mathrm{O}_{3}$ when the Mn loading was higher than $2.4 \mathrm{wt} \%$.

Based on the above results, it is reasonable to suggest that the AgMn/HZ(2.4) catalyst has high activity and stability during OZCO of benzene and is promising for benzene removal.

The $B^{0 Z C_{C}}$ values for $\mathrm{Ag} / \mathrm{HZ}$ and $\mathrm{AgMn} / \mathrm{HZ}(2.4)$ are compared in Fig. 6. The $B^{0 Z C}{ }_{C}$ of $\mathrm{AgMn} / \mathrm{HZ}(2.4)$ was higher than that of $\mathrm{Ag} / \mathrm{HZ}$ during the entire reaction, but neither of them reached $100 \%$. The addition of $\mathrm{MnO}_{x}$ facilitated benzene oxidation, and the imperfect $B^{0 z C O}{ }_{C}$ showed the formation of organic byproducts on the catalyst surface, and the build-up of byproducts was the main cause of catalyst deactivation [11].

The TPO profiles of the used AgMn/HZ(2.4) catalyst are shown in Fig. 7. In addition to desorbed benzene and $\mathrm{HCOOH}$ (Fig. 7(a)), $\mathrm{CO}_{2}$ and $\mathrm{CO}$ were formed as primary products. Two peaks were observed, for the formation of $\mathrm{CO}_{2}$ and $\mathrm{CO}$ (Fig.
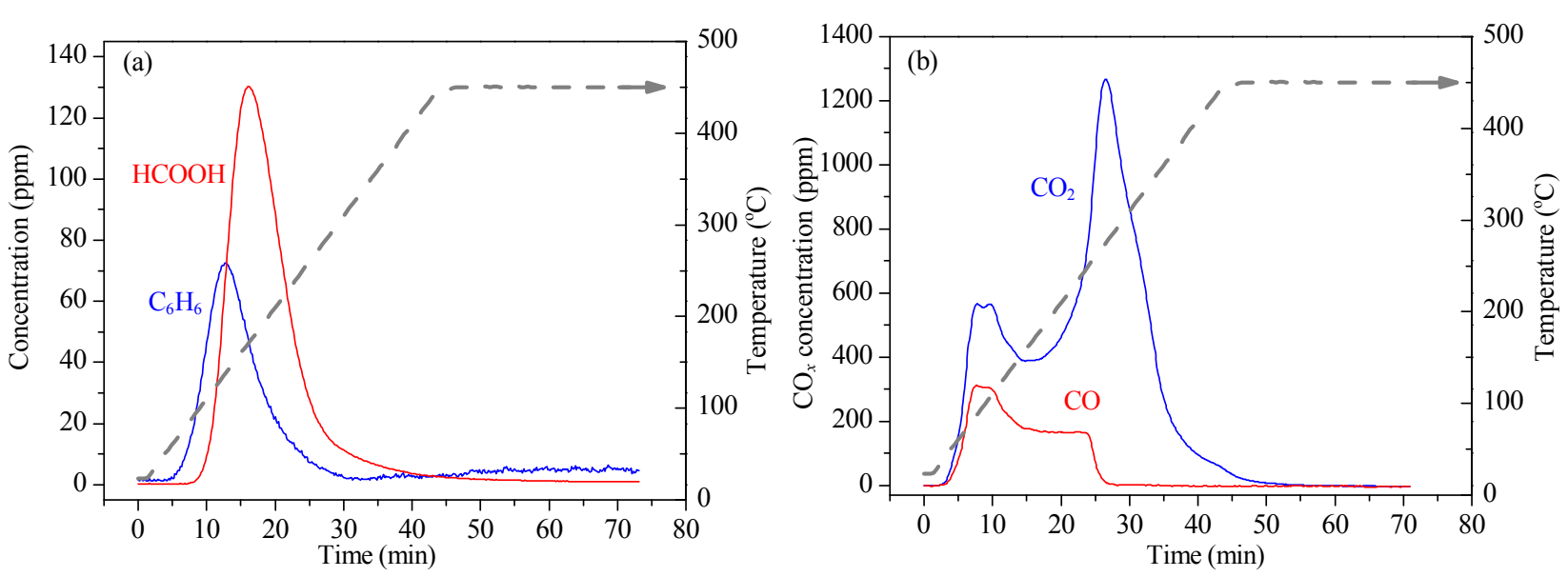

Fig. 7. TPO profiles of used $\mathrm{AgMn} / \mathrm{HZ}(2.4)$ catalyst after OZCO for 120 min. (a) Benzene and $\mathrm{HCOOH}$ concentrations; (b) $\mathrm{CO}_{x}$ concentration. TPO conditions: 90 SCCM of dry simulated air, $10^{\circ} \mathrm{C} / \mathrm{min}$.

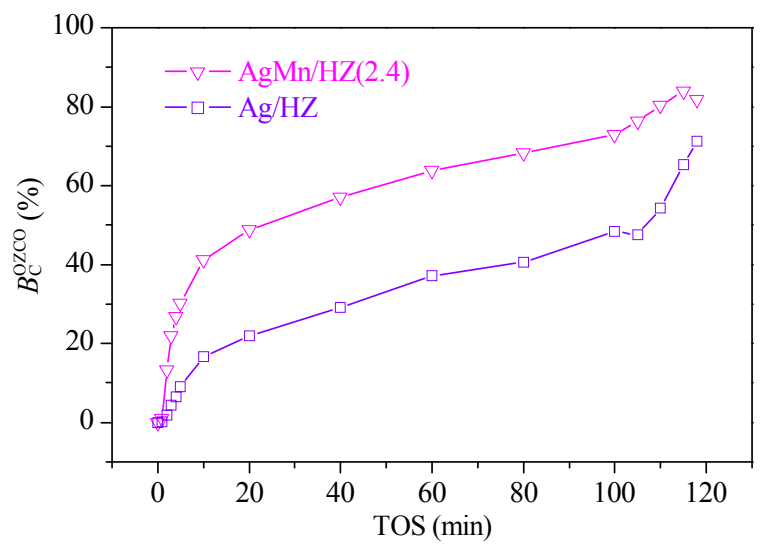

Fig. 6. $B^{0 Z C_{C}}$ values for $\mathrm{Ag} / \mathrm{HZ}$ and $\mathrm{AgMn} / \mathrm{HZ}(2.4)$ catalysts during OZCO of benzene in dry continuous air flow.

7(b)). The peaks at low temperatures corresponded to the desorption of $\mathrm{CO}_{2}$ and $\mathrm{CO}$ formed in OZCO; the peaks at higher temperatures were assigned to oxidation of residual benzene and intermediate products such as formates and carboxylates. The TPO results confirm that the $\mathrm{BOZCO}_{\mathrm{C}}$ was imperfect because of residual benzene or its derivatives on the catalysts after OZCO of benzene.

\subsection{TPD investigation of surface species after OZCO of gaseous} benzene

To identify the surface species present after OZCO, TPD investigations were carried out on the used catalysts after OZCO of benzene. Figure 8 shows the TPD results for the used $\mathrm{Ag} / \mathrm{HZ}$ and AgMn/HZ catalysts. Two benzene evolution peaks were observed for the $\mathrm{Ag} / \mathrm{HZ}$ and $\mathrm{AgMn} / \mathrm{HZ}$ catalysts (Fig. 8(a)). The low-temperature peaks correspond to desorption of benzene from the HZ support, and the high-temperature peaks are assigned to desorption of benzene from $\mathrm{Ag}$, as discovered by our previous study. The benzene desorption was plotted against Mn loading for quantification; the results are shown in Fig. 8(c). The benzene desorption did not vary much at high temperatures (Fig. 8(c)). However, the benzene desorption at low temperatures decreased significantly from $\mathrm{Ag} / \mathrm{HZ}$ to $\mathrm{AgMn} / \mathrm{HZ}(2.4)$ 

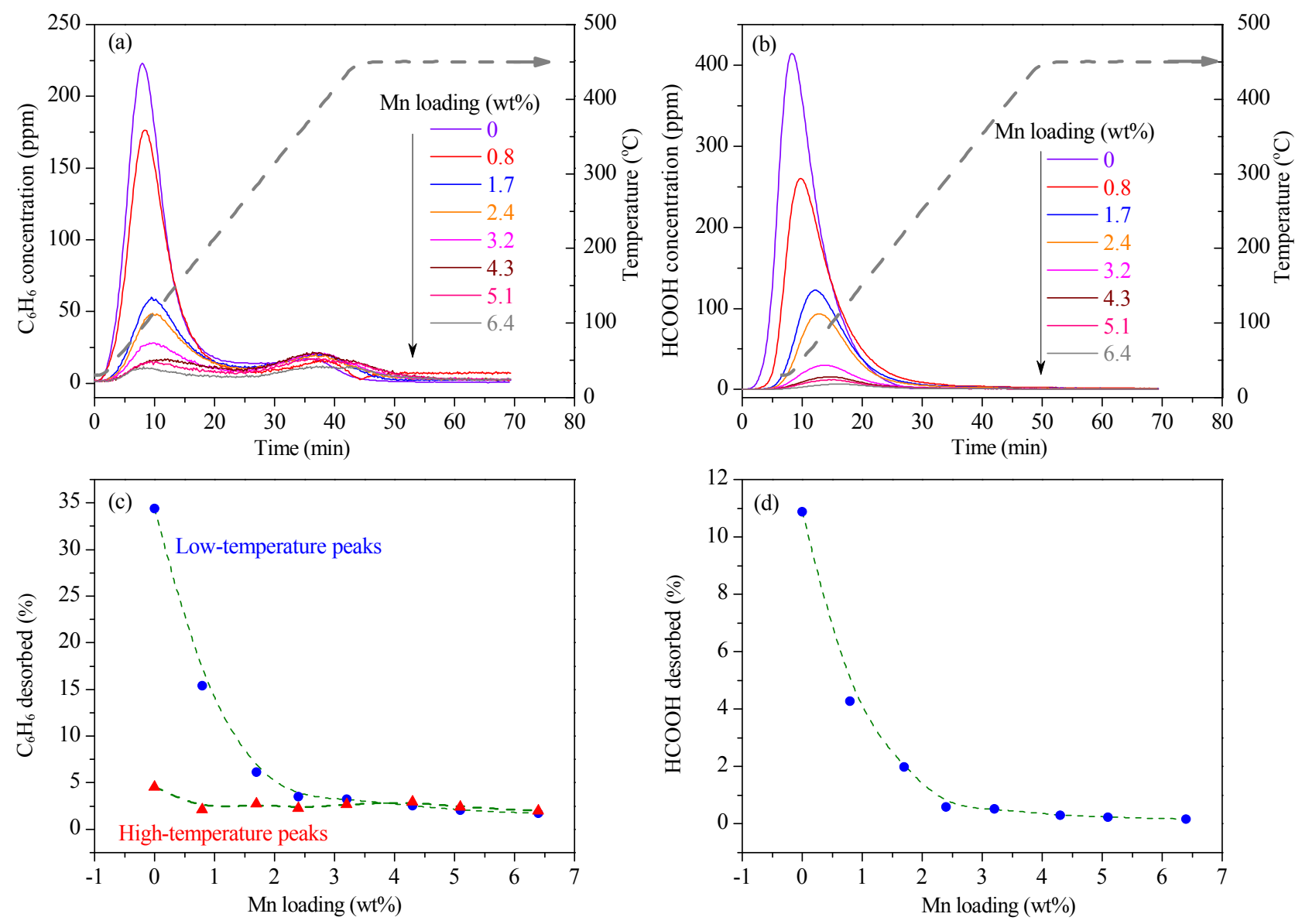

Fig. 8. TPD profiles of used catalysts after OZCO of benzene for $120 \mathrm{~min}$ in dry continuous air flow. (a) Benzene concentration; (b) HCOOH concentration; (c) Dependence of benzene desorption on Mn loading; (d) Dependence of HCOOH desorption on Mn loading. TPD conditions: 90 SCCM of N2, 10 ${ }^{\circ} \mathrm{C} / \mathrm{min}$.

and then remained almost constant with increasing Mn loading. In addition to benzene, $\mathrm{HCOOH}$ was detected during TPD, and the time courses for $\mathrm{HCOOH}$ concentration are shown in Fig. 8(b). $\mathrm{HCOOH}$ was evolved as a result of desorption of $\mathrm{HCOOH}$ formed during OZCO. Quantification of desorbed $\mathrm{HCOOH}$ was also carried out, and the results are displayed in Fig. 8(d). The trend in the dependence of desorbed $\mathrm{HCOOH}$ on Mn loading was the same as that for the dependence of desorbed benzene on Mn loading. The TPD results reveal that $2.4 \mathrm{wt} \%$ is the minimum Mn loading for suppressing the accumulation of benzene and $\mathrm{HCOOH}$ on the catalyst surface during benzene oxidation.

\section{4. $\mathrm{O}_{3}$ decomposition without benzene}

Figure 9(a) shows the time profiles for $\mathrm{O}_{3}$ decomposition in the absence of benzene over the $\mathrm{Ag} / \mathrm{HZ}$ and $\mathrm{AgMn} / \mathrm{HZ}$ catalysts. The decomposition behavior was very different from that for $\mathrm{O}_{3}$ decomposition with benzene (Fig. 4(b)); this might be caused by the different reaction atmospheres. It can be seen from Fig. 9(a) that the AgMn/HZ catalysts performed better than the $\mathrm{Ag} / \mathrm{HZ}$ catalyst; this can be ascribed to the very high activities of manganese oxides in $\mathrm{O}_{3}$ decomposition [11,19,20,36-38]. For AgMn/HZ catalysts with different Mn loadings, the $\mathrm{O}_{3}$ decomposition did not change regularly with
Mn loading. However, if the mechanism of $\mathrm{O}_{3}$ decomposition is taken into consideration, a linear correlation between $\mathrm{O}_{3}$ decomposition and $\mathrm{Mn}^{3+}$ content (wt $\%$ ) is found. $\mathrm{O}_{3}$ decomposition is a redox process, and Oyama and coworkers [39] have reported that $\mathrm{O}_{3}$ decomposition on $\mathrm{MnO}_{x} / \mathrm{Al}_{2} \mathrm{O}_{3}$ catalysts proceeded by electron transfer from $\mathrm{Mn}$ sites to $\mathrm{O}_{3}$, and $\mathrm{Mn}$ was reduced by desorption of oxygen species. Based on this assumption, it is reasonable to suppose that $\mathrm{MnO}_{x}$ with low $\mathrm{Mn}$ valence is favorable for $\mathrm{O}_{3}$ decomposition. Based on the $\mathrm{Mn}^{3+} / \mathrm{Mn}^{4+}$ atomic ratios obtained in $\mathrm{H}_{2}$-TPR experiments, the Mn loading, the mass of catalyst used, the $\mathrm{Mn}^{3+}$ content for each AgMn/HZ catalyst could therefore be calculated. Figure 9(b) shows the effects of the $\mathrm{Mn}^{3+}$ contents of the $\mathrm{AgMn} / \mathrm{HZ}$ catalysts on $\mathrm{O}_{3}$ decomposition at TOS $=120 \mathrm{~min}$. A good linear relationship between $\mathrm{O}_{3}$ decomposition and $\mathrm{Mn}^{3+}$ content was observed. These findings show that the $\mathrm{Mn}^{3+}$ content is the key parameter in determining the $\mathrm{O}_{3}$ decomposition activities of the $\mathrm{AgMn} / \mathrm{HZ}$ catalysts, and that $\mathrm{AgMn} / \mathrm{HZ}$ catalysts with high $\mathrm{Mn}^{3+}$ contents are effective for $\mathrm{O}_{3}$ decomposition. Similar results were also obtained by Rezaei et al. [20], who found that the lower oxidation states of $\mathrm{Mn}$ were more favorable in $\mathrm{O}_{3}$ decomposition. It should be specifically pointed out that although the AgMn/HZ(4.3) catalyst gave the best $\mathrm{O}_{3}$ decomposition without benzene, it did not show the highest benzene conversion during OZCO (Fig. 4(a)); this was a result of its poor 

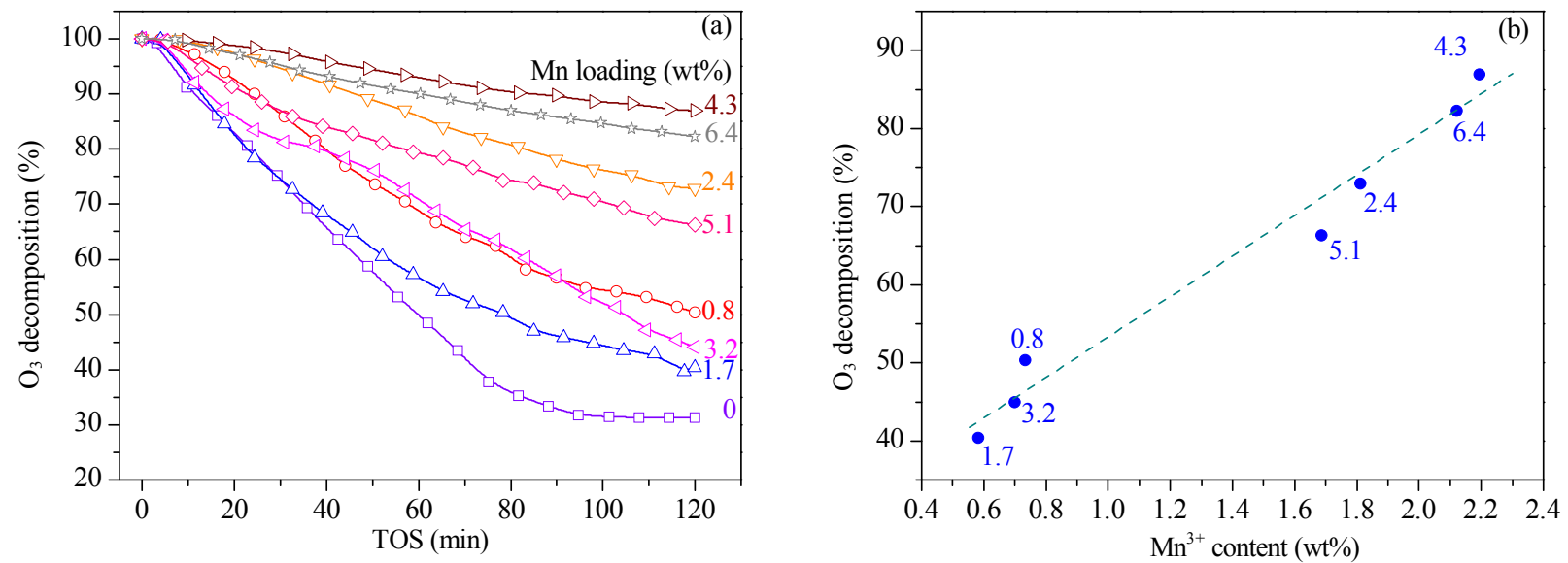

Fig. 9. (a) Time courses for $\mathrm{O}_{3}$ decomposition without benzene over $\mathrm{Ag} / \mathrm{HZ}$ and $\mathrm{AgMn} / \mathrm{HZ}$ catalysts; (b) Effect of $\mathrm{Mn}^{3+}$ content on $\mathrm{O}_{3}$ decomposition at TOS $=120$ min. $\mathrm{O}_{3}$ decomposition conditions: $27 \mathrm{mg}$ of catalyst, $100 \mathrm{SCCM}$ of $\mathrm{O}_{3} / \mathrm{O}_{2}$, and $862-921 \mathrm{mg} / \mathrm{m}^{3} \mathrm{O}_{3}$. Numbers in (b) represent the Mn loadings (wt\%) of AgMn/HZ catalysts.
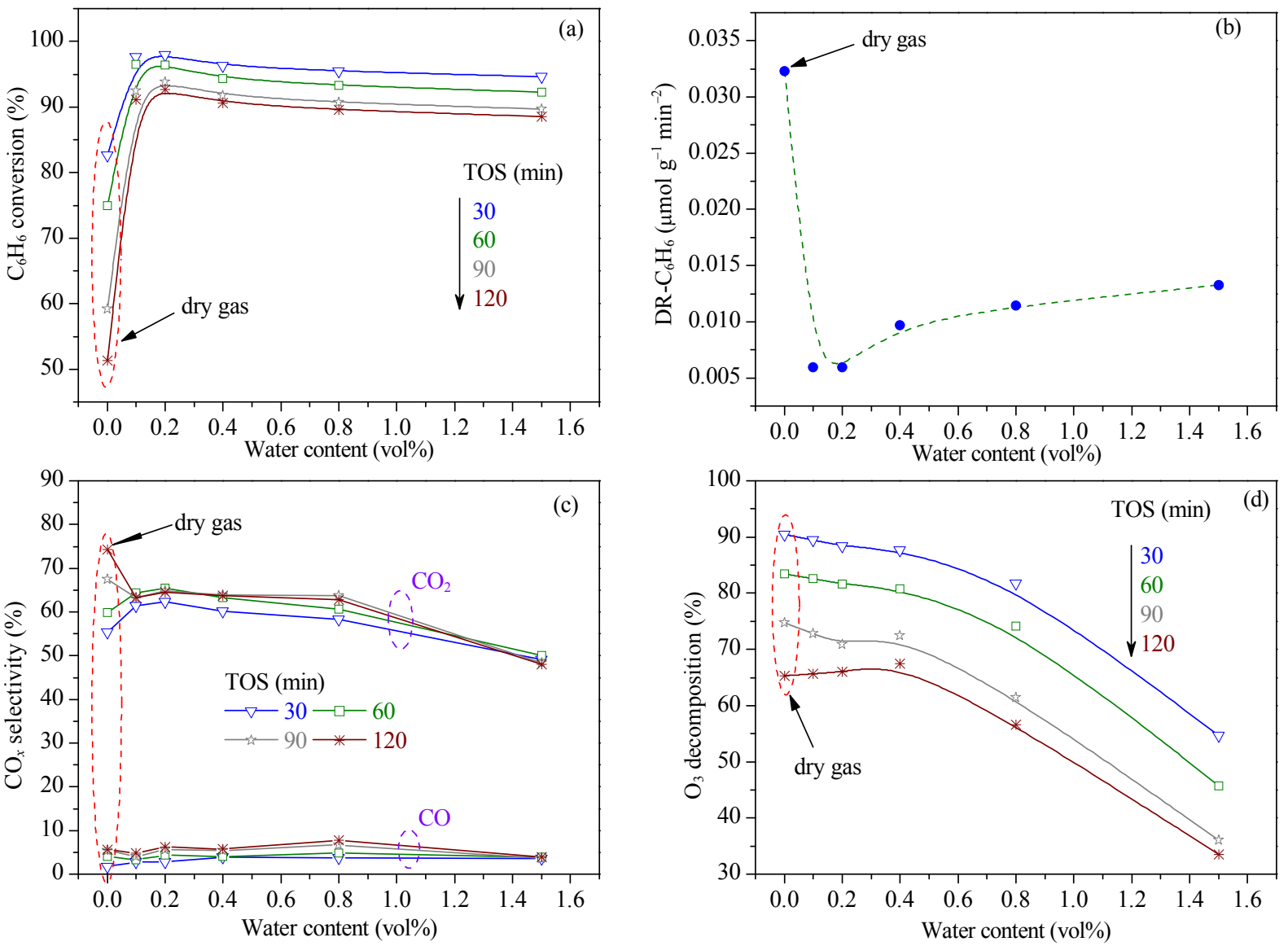

Fig. 10. Effects of water content on benzene conversion (a), $\mathrm{CO}_{x}$ selectivity (c), and $\mathrm{O}_{3}$ decomposition (d) at different TOS and dependence of catalyst deactivation rate on water content (b) for OZCO of benzene in humid continuous air flow over AgMn/HZ(2.4) catalyst. OZCO conditions: 53 mg of catalyst, $143-153 \mathrm{mg} / \mathrm{m}^{3}$ benzene in dry simulated air at $250 \mathrm{SCCM}$, and $862-901 \mathrm{mg} / \mathrm{m}^{3} \mathrm{O}_{3}$.

benzene activation ability because benzene activation was crucial when the Mn loading was higher than $2.4 \mathrm{wt} \%$.

\subsection{Effect of water vapor on OZCO over AgMn/HZ(2.4) catalyst}

The above results show that the $\mathrm{AgMn} / \mathrm{HZ}(2.4)$ catalyst is promising for benzene oxidation using $\mathrm{O}_{3}$. However, the pres- ence of water vapor is inevitable under real conditions. The effects of water vapor over the AgMn/HZ(2.4) catalyst for five water contents, i.e., $0.1,0.2,0.4,0.8$, and 1.5 vol\%, were investigated.

Figure 10(a) shows the effect of water content on benzene conversion over the $\mathrm{AgMn} / \mathrm{HZ}(2.4)$ catalyst. Compared with a dry air stream, water vapor greatly enhanced the catalytic ac- 
tivity. Figure 10(a) also shows that $0.1-0.2$ vol\% water in the reaction gas resulted in higher activity, but further increases in the water content gradually decreased the catalytic activity, as a result of blockage of the active catalytic sites by excess water molecules. Figure $10(\mathrm{~b})$ shows the dependence of DR- $\mathrm{C}_{6} \mathrm{H}_{6}$ on the water content. Water vapor significantly improved the catalyst stability, and 0.1-0.2 vol\% water gave the best stability. Several authors have reported positive effects of water vapor on OZCO [22-24,40], and these findings indicate that water vapor could suppress catalyst deactivation by inhibiting the build-up of organic byproducts on the catalyst surface. The $\mathrm{CO}_{2}$ selectivity (Fig. 10(c)) was also promoted by water addition when the water contents were $\leq 0.8$ vol\%, and similar $\mathrm{CO}_{2}$ selectivities were obtained when the water contents were $\leq 0.4$ vol\%. When the water content was increased to $1.5 \mathrm{vol} \%$, the $\mathrm{CO}_{2}$ selectivity dropped below that in a dry stream. It should be noted that during reaction for 90-120 min, the $\mathrm{CO}_{2}$ selectivity in a dry air stream became higher than those in humid streams. This is because in a dry stream the benzene conversion decreased sharply with increasing TOS, as shown in Fig. 10(a), but the $\mathrm{CO}_{2}$ concentration did not decrease much (data not shown). Although water vapor has a clear effect on $\mathrm{CO}_{2}$ selectivity, the CO selectivity was almost the same in dry and humid streams (Fig. 10(c)). Figure 10(d) shows the variations in $\mathrm{O}_{3}$ decomposition with Mn loading at different TOS over the AgMn/HZ(2.4) catalyst in dry and humid air streams. Different water contents affected $\mathrm{O}_{3}$ decomposition to different extents. When 0.1-0.4 vol\% of water was added, the decomposition behavior was similar to that in a dry air stream, but the percentage of $\mathrm{O}_{3}$ decomposition was much lower in the cases of 0.8 vol\% and 1.5 vol\% water. Water addition did not promote $\mathrm{O}_{3}$ decomposition, so why did water vapor enhance benzene removal (Fig. 10(a))? There are two possible reasons. One is that the formation of byproducts on the catalyst surface was crucial for benzene oxidation with $\mathrm{O}_{3}$ [27]. It is therefore likely that suppression of the formation of organic byproducts by water vapor played an important role in benzene oxidation in a humid stream. The other is that more-active oxygen species (such as hydroxyl radicals) were formed on the catalyst surface in a humid stream [24], and this would promote benzene oxidation.

\section{Conclusions}

The effects of Mn loading and water content on OZCO of benzene over $\mathrm{AgMn} / \mathrm{HZ}$ catalysts were studied in a continuous air flow. The addition of $\mathrm{MnO}_{x}$ not only enhanced benzene conversion and $\mathrm{O}_{3}$ decomposition compared with those achieved using $\mathrm{Ag} / \mathrm{HZ}$ but also increased the $\mathrm{CO}_{2}$ selectivity. The $\mathrm{AgMn} / \mathrm{HZ}$ catalyst with a $2.4 \mathrm{wt} \% \mathrm{Mn}$ loading had the highest activity and stability in benzene oxidation, but further increases in the Mn loading decreased the catalytic activity and stability because of the decreased surface area, poor $\mathrm{MnO}_{x}$ dispersion, and the coverage of $\mathrm{Ag}$ by $\mathrm{MnO}_{x}$ particles, which would hinder benzene activation. TPD results for the used catalysts showed that $2.4 \mathrm{wt} \%$ was also the optimal Mn loading for suppressing the accumulation of benzene and $\mathrm{HCOOH}$ on the catalyst surface after benzene oxidation. When the Mn loading was lower than $2.4 \mathrm{wt} \%, \mathrm{O}_{3}$ decomposition to active oxygen species $\left(\mathrm{O}^{*}\right)$ played the most important role in benzene oxidation, whereas benzene activation was the crucial step for benzene oxidation by $\mathrm{O}_{3}$ when the Mn loading was higher than $2.4 \mathrm{wt} \%$. Water vapor suppressed catalyst deactivation and greatly enhanced the catalytic activity; $0.1-0.2$ vol\% water was the optimal water content for benzene oxidation.

\section{References}

[1] Whysner J, Reddy M V, Ross P M, Mohan M, Lax E A. Mutat Res, 2004, 566: 99

[2] Zhao D Z, Ding T Y, Li X S, Liu J L, Shi C, Zhu A M. Chin J Catal (赵德

\section{Graphical Abstract}

Chin. J. Catal., 2014, 35: 1465-1474 doi: 10.1016/S1872-2067(14)60070-X

Ozone catalytic oxidation of benzene over AgMn/HZSM-5 catalysts at room temperature: Effects of Mn loading and water content

Yang Liu, Xiaosong Li, Jinglin Liu, Chuan Shi, Aimin Zhu*

Dalian University of Technology

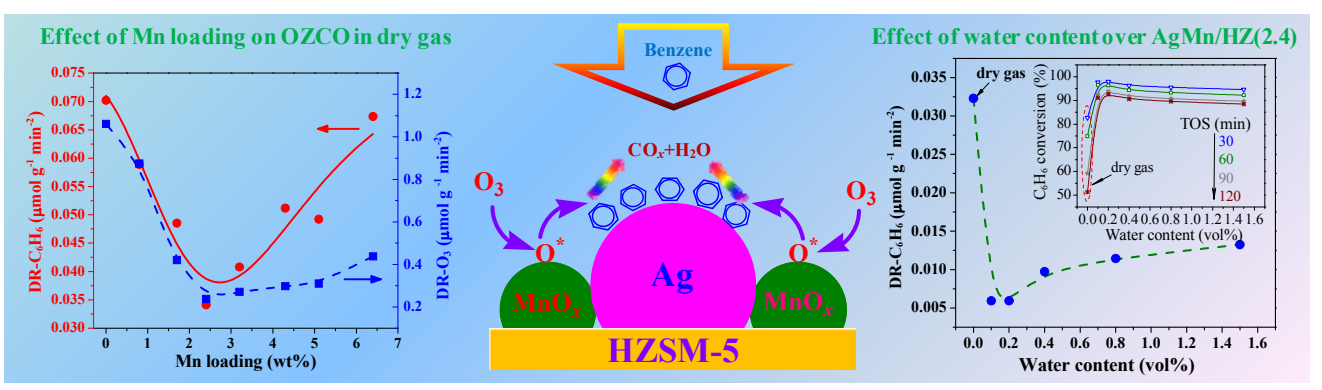

AgMn/HZSM-5 catalyst with Mn loading of $2.4 \mathrm{wt} \%$ has the best activity and stability. $\mathrm{O}_{3}$ decomposition is crucial for AgMn/HZSM-5 (Mn loading $\leq 2.4 \mathrm{wt} \%$ ), whereas benzene activation is important for AgMn/HZSM-5 (Mn loading > 2.4 wt\%). Water vapor greatly enhances the OZCO reactivity and stability. 
志, 丁天英, 李小松, 刘景林, 石川, 朱爱民. 催化学报), 2012, 33: 396

[3] Kasprzyk-Hordern B, Ziółek M, Nawrocki J. Appl Catal B, 2003, 46: 639

[4] Xiao H, Liu R P, Zhao X, Qu J H. Chemosphere, 2008, 72: 1006

[5] Long L P, Zhao J G, Yang L X, Fu M L, Wu J L, Huang B C, Ye D Q. Chin J Catal (龙丽萍, 赵建国, 杨利娴, 付名利, 吴军良, 黄碧纯, 叶代启. 催化学报), 2011, 32: 904

[6] Konova P, Stoyanova M, Naydenov A, Christoskova St, Mehandjiev D. Appl Catal A, 2006, 298: 109

[7] Naydenov A, Mehandjiev D. Appl Catal A, 1993, 97: 17

[8] Mehandjiev D, Cheshkova K, Naydenov A, Georgesku V. React Kinet Catal Lett, 2002, 76: 287

[9] Dimitrova S, Ivanov G, Mehandjiev D. Appl Catal A, 2004, 266: 81

[10] Stoyanova M, Konova P, Nikolov P, Naydenov A, Christoskova St, Mehandjiev D. Chem Eng J, 2006, 122: 41

[11] Einaga H, Futamura S. J Catal, 2004, 227: 304

[12] Einaga H, Ogata A. J Hazard Mater, 2009, 164: 1236

[13] Einaga H, Futamura S. React Kinet Catal Lett, 2004, 81: 121

[14] Einaga H, Harada M, Ogata A. Catal Lett, 2009, 129: 422

[15] Mehandjiev D, Zhecheva E, Ivanov G, Ioncheva R. Appl Catal A 1998, 167: 277

[16] Mehandjiev D, Naydenov A, Ivanov G. Appl Catal A, 2001, 206: 13

[17] Naydenov A, Stoyanova R, Mehandjiev D. J Mol Catal A, 1995, 98: 9

[18] Einaga H, Ogata A. Environ Sci Technol, 2010, 44: 2612

[19] Rezaei E, Soltan J. Chem Eng J, 2012, 198-199: 482

[20] Rezaei E, Soltan J, Chen N. Appl Catal B, 2013, 136-137: 239

[21] Rezaei E, Soltan J, Chen N, Lin J R. Chem Eng J, 2013, 214: 219

[22] Einaga H, Futamura S. J Catal, 2006, 243: 446

[23] Einaga H, Teraoka Y, Ogat A. Catal Today, 2011, 164: 571
[24] Zhao D Z, Shi C, Li X S, Zhu A M, Jang B W L. J Hazard Mater, 2012, 239-240: 362

[25] Wang M X, Zhang P Y, Li J G, Jiang C J. Chin J Catal (王鸣晓, 张彭义, 李金格, 姜传佳. 催化学报), 2014, 35: 335

[26] Wang M Y, Zhu T L, Fan X. Chin Environ Sci (王美艳, 朱天乐, 森星. 中国环境科学), 2009, 29: 806

[27] Einaga H, Teraoka Y, Ogat A. J Catal, 2013, 305: 227

[28] Fan H Y, Shi C, Li X S, Zhao D Z, Xu Y, Zhu A M. J Phys D, 2009, 42: 225105

[29] Fan H Y, Li X S, Shi C, Zhao D Z, Liu J L, Liu Y X, Zhu A M. Plasma Chem Plasma Process, 2011, 31: 799

[30] Zhao D Z, Li X S, Shi C, Fan H Y, Zhu A M. Chem Eng Sci, 2011, 66: 3922

[31] Qu Z P, Bu Y B, Qin Y, Wang Y, Fu Q. Appl Catal B, 2013, 132-133: 353

[32] Bogdanchikova N, Meunier F C, Avalos-Borja M, Breen J P, Pestryakov A. Appl Catal B, 2002, 36: 287

[33] Shi C, Chen B B, Li X S, Crocker M, Wang Y, Zhu A M. Chem Eng J, 2012, 200-202: 729

[34] Ma F T, Lou H. Chin J Catal (马福泰, 楼辉. 催化学报), 1984, 5: 82

[35] Boot L A, Kerkhoffs M H J V, van der Linden B T, Jos van Dillen A, Geus J W, van Buren F R. Appl Catal A, 1996, 137: 69

[36] Dhandapani B, Oyama S T. Appl Catal B, 1997, 11: 129

[37] Oyama S T. Catal Rev-Sci Eng, 2000, 42: 279

[38] Wang H C, Chang S H, Hung P C, Hwang J F, Chang M B. J Hazard Mater, 2009, 164: 1452

[39] Radhakrishnan R, Oyama S T, Chen J G, Asakura K. J Phys Chem B, 2001, 105: 4245

[40] Wang H C, Chang S H, Hung P C, Hwang J F, Chang M B. Chemosphere, 2008, 71: 388

\title{
$A g M n / H Z S M-5$ 催化剂上室温 $O_{3}$ 氧化脱除空气中的苯: Mn含量和水含量的影响
}

\author{
刘阳，李小松，刘景林，石川，朱爱民* \\ 大连理工大学等离子体物理化学实验室, 辽宁大连 116024
}

摘要: 考察了 $\mathrm{Mn}$ 含量和水含量对 $\mathrm{AgMn} / \mathrm{HZSM}-5(\mathrm{AgMn} / \mathrm{HZ})$ 催化剂上室温 $\mathrm{O}_{3}$ 氧化 $(\mathrm{OZCO})$ 脱除空气中苯的影响. 研究发现, $\mathrm{Mn}$ 含 量为 $2.4 \mathrm{wt} \%$ 的 $\mathrm{AgMn} / \mathrm{HZ}$ 催化剂 $(\mathrm{AgMn} / \mathrm{HZ}(2.4))$ 具有大的比表面积和高的 $\mathrm{MnO}_{x}$ 分散度, OZCO活性和稳定性最高. 反应后的程序 升温脱附结果表明, $2.4 \mathrm{wt} \%$ 的 $\mathrm{Mn}$ 含量能有效抑制苯和甲酸在催化剂上的残留. 当 $\mathrm{Mn}$ 含量 $\leqslant 2.4 \mathrm{wt} \%$ 时, 催化剂分解 $\mathrm{O}_{3}$ 的活性在 苯氧化过程中占主导; 当 $\mathrm{Mn}$ 含量 $>2.4 \mathrm{wt} \%$ 时, 苯的活化起主要作用. 基于 $\mathrm{AgMn} / \mathrm{HZ}(2.4)$ 催化剂优越的反应活性和稳定性, 进一 步研究了湿气流中该催化剂上苯的氧化. 与干气流相比, 水汽的加入能显著提高催化剂的反应活性和稳定性, 且以 $0.1-0.2 \mathrm{vol} \%$ 水 含量时最优.

关键词：催化氧化苯; 臭氧; AgMn/HZSM-5催化剂; Mn含量; 水含量

收稿日期: 2014-01-22. 接受日期: 2014-03-03. 出版日期: 2014-09-20.

*通讯联系人. 电话/传真: (0411)84706094; 电子信箱：amzhu@dlut.edu.cn

基金来源：国家自然科学基金(U1201231, 11175036).

本文的英文电子版由Elsevier出版社在ScienceDirect上出版(http://www.sciencedirect.com/science/journal/18722067). 